\title{
PROBLEMS RAISED BY NOXES CONTROL AT FCAW
}

\author{
MOISA, R[aul]; POPESCU, M[ihaela] \& OPRIS, C[armen]
}

\begin{abstract}
Flux cored arc welding (FCAW) is applied due to its remarkable results and advantages (high productivity, joint quality, good aspect of the joints etc) in various fields (industrial construction, naval, chemistry, petrochemistry etc.). FCAW disadvantages, mainly the emission of pollutants, can be counteracted by their rigorous control and local forced ventilation in the production.
\end{abstract}

Key words: noxes, FCAW, ventilation, protective devices

\section{INTRODUCTION}

Flux Cored Arc Welding process (FCAW) gains field for joining processes as well as for coatings. FCAW leads to obtain joints with exceptional quality, in conditions of high productivity, while in the case of welding reconditioning, it is necessary to rebuild or to coat active parts of the components submitted to certain loads, such as abrasion or moderate impact. The main disadvantage of using tubular wire for welding consists in massive noxes emissions. From here results the necessity of measuring "in situ" the noxes content, with the specific purpose to verify their framing within admissible limits, as given by the occupational health organisms. The problem of ensuring environmental protection at FCAW is of strict actuality. Flux cored arc welding (FCAW) is applied due to its remarkable results and advantages (high productivity, joint quality etc) in various fields. FCAW emission of pollutants can be counteracted by their rigorous control and local forced ventilation in the production.

\section{GENERAL PROBLEMS AT FCAW WELDING}

Flux cored arc welding (FCAW) has a wide applicability, due to its numerous advantages: a FCAW provides high quality weld metal at lower cost with less effort on the part of the welder than SMAW. It is more forgiving than gas metal arc welding and is more flexible and adaptable than submerged arc welding - Excellent weld appearance smooth and uniform welds, less liable to porosity Relatively high travel speeds

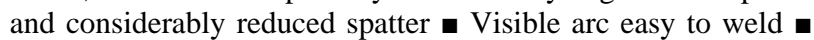
Excellent contour of horizontal fillet welds - FCAW welds a variety of steels over a wide thickness range - High deposition rate, high current density. - Reduced distortion over shielded metal arc welding (SMAW) - High operating factor can is easily mechanized - Economical engineering joint designs Less pre cleaning required than gas metal arc welding.

The limitations of FCAW regarding its applicability are as follows: - Used only to weld ferrous metals, primarily steels $~$ FCAW produces a slag covering which has to be removed Electrode wire is more expensive on a weight basis than solid electrode wires - Equipment is more expensive and complex than required for shielded metal arc welding; however the increased productivity compensates for this - Earlier, self shielding wires, because of their limited mechanical properties and their inability to operate in vertical and overhead positions could not become popular. These inadequacies have now been overcome and today FCAW is widely used for all position welding.

Important to mention are the numerous applications of FCAW, such as: - FCAW is replacing SMAW for many applications, replacing GMAW, primarily the $\mathrm{CO}_{2}$ version, and replacing submerged arc welding (SAW) for thinner metal m FCAW is also used for surfacing and for buildup - The metals weldable by FCAW are: Cast iron, low carbon steel, low alloy steel, high and medium carbon steel, alloy steels, stainless steels limited types - FCAW has been widely used for welding in bridges, high rise buildings, ship building and offshore drilling platforms, main frames on bulldozers, rotating frames for shovels and cranes, tractor frames, bridge girders, large gantry cranes, furnace tubes, diesel engine chassis etc.

\section{EFFECTS OF THE DECOMPOSITION PRODUCTS AT FCAW WELDING}

Welding fumes and gases and the composition and quantity of both are dependent upon the metal being welded, the process, procedures, and electrodes used. Decomposition products of normal operation include those originating from the volatilization, reaction, or oxidation of the materials, plus those from the base metal and coating etc. It is understood, however, that the elements and/or oxides to be mentioned are virtually always present as complex oxides and not as metals. The elements or oxides listed in table 1 correspond to the ACGIH categories located in [TLV Threshold Limit Values for Chemical Substances and physical Agents in the Workroom Environment]. Expected constituents of the fume would include: complex oxides of iron, manganese, silicon, titanium, magnesium, barium and aluminum. Fluorides are also present.

\begin{tabular}{|c|c|c|}
\hline \multirow[t]{2}{*}{ Substance } & \multicolumn{2}{|c|}{ Exposure Limit $\left(\mathrm{mg} / \mathrm{m}^{3}\right)$} \\
\hline & OSHA PEL & ALGIH TLV \\
\hline Iron Oxide & 5 & $10\left(\right.$ as $\left.\mathrm{Fe}_{2} \mathrm{O}_{3}\right)$ \\
\hline Manganese & $5 \mathrm{CL}^{*}$ & $1 \mathrm{CL}^{*}$ (fume) \\
\hline Silicon Oxide & 5 & 3 \\
\hline Titanium Oxide & 15 & 10,20 STEL $* *$ \\
\hline Magnesium Oxide & 15 & 10 \\
\hline Fluorides & 2.5 (as F) & 2.5 (as F) \\
\hline Aluminum Oxide & nothing found & 10 \\
\hline ***Nickel (Soluble) & 1 (as Ni) & 0.1 (as $\mathrm{Ni}$ ) \\
\hline ***Nickel Oxide & nothing found & 1 (as Ni) \\
\hline Barium & 0.5 (sol.) & 0.5 \\
\hline
\end{tabular}

Tab. 1. Substances and exposure limits

\section{CONTROL MEASURES AND PRECAUTIONS FOR SAFE HANDLING AND USE}

Some of the precaution measures to be taken when using

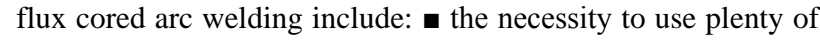


ventilation and/or local exhaustion at the arc, to keep the fumes and gases below the threshold limit value within the worker's breathing zone and the general work area $\boldsymbol{m}$ it is recommended to use respiratory protective devices (RPD) when welding in a confined space or general work area where local exhaust and/or ventilation does not keep exposure below the threshold limit

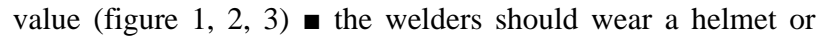
face shield with a filter lens shade number 12-14 or darker the personnel must wear approved head, hand and body protection which help to prevent injury from radiation, sparks and electrical shock. The persons responsible for welding are forced, by legislation and by the regulations of Occupational Safety and Health Administration (OSHA) to apply direct measures to control the noxes emissions and to fit the Permissible Exposure Limit (PEL).

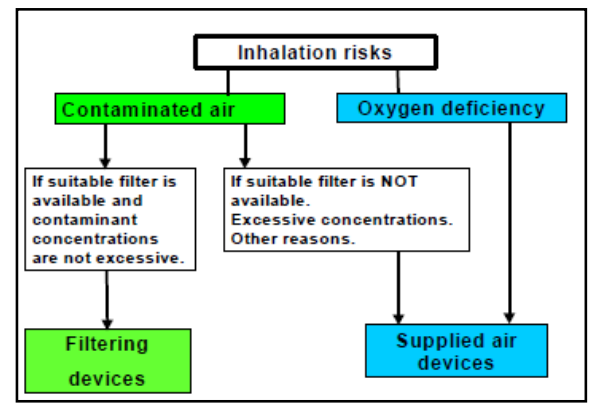

Fig. 1. Major categories of respiratory protective devices: filtering devices and supplied air devices

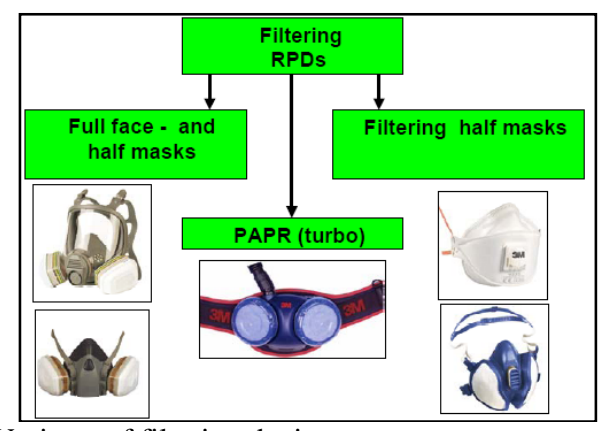

Fig. 2. Variants of filtering devices

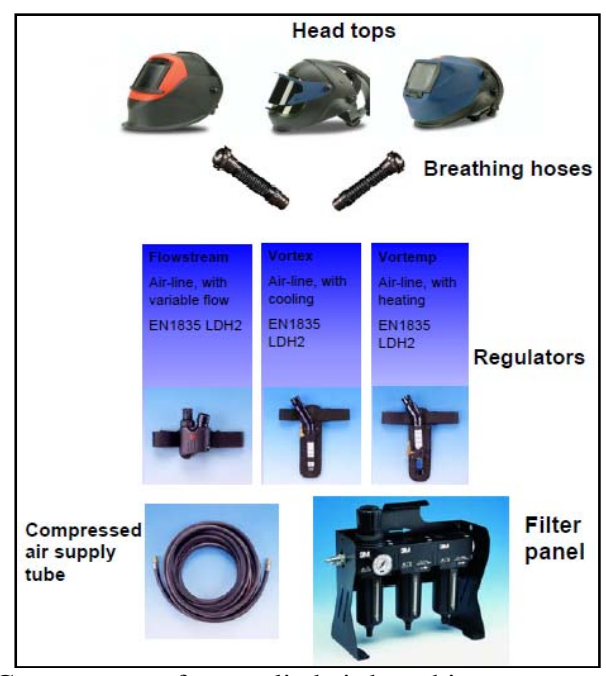

Fig. 3. Components of a supplied air breathing apparatus

\section{CASE STUDY}

New generation flux cored arc wire have been produced lately, such as „low fume” tubular wire, Stardual 208 HP, T 42 $3 \mathrm{M} \mathrm{M} 1 \mathrm{H} 5$ according to EN ISO 17632-A, that ensure low levels of fumes at welding. This new „low fume” copper coated metal cored wire generates less fume than similar standard products. It enables fume emission rate reduction of up to $40 \%$ (standard shielding gas M 21). Other advantages include: slag less metal powder tubular cored wire with outstanding welding properties in the short-arc and spray-arc ranges a almost splatter free when welding in the spray-arc range a provides good restriking, even with a cold the wire tip, thus being suitable for a robot applications.

Characteristics that recommend this type of wire for FCAW are: high deposition rate and welding speed, good wall fusion, finely rippled welds, without undercutting into the base metal, not even on contaminated or corroded metal surfaces.

Main applications for these types of wire are: shipbuilding; rolling stock construction; structural steelwork, boiler-works; bridge cranes, cranes, earth moving machines.

Welding positions that are recommended for this type of wire are presented in figure 4 . Technical data include: current: DC+, gas: M21 ( $\mathrm{Ar} / \mathrm{CO}_{2}$, Diffusible $\mathrm{H}_{2}: 3 \mathrm{ml} / 100 \mathrm{~g}$ max.).

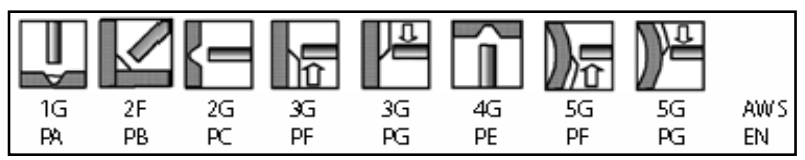

Fig. 4. Recommended welding positions for T $423 \mathrm{M} \mathrm{M} 1 \mathrm{H} 5$ wire

Deposited metal submitted to chemical analysis gives results presented in table 3 , while mechanical characteristics are presented in table 4 .

\begin{tabular}{|c|c|c|c|c|c|}
\hline Gas & C & Mn & $\mathrm{Si}$ & $\mathrm{S}$ & $\mathrm{P}$ \\
\hline $\mathrm{Ar}-\mathrm{CO}_{2}$ & 0.02 & 1.6 & 0.8 & $\leq 0.005$ & $\leq 0.013$ \\
\hline
\end{tabular}

Tab. 3. Chemical analysis results for the deposited metal

\begin{tabular}{|c|c|c|c|c|c|}
\hline Gas & $\begin{array}{c}\text { Heat } \\
\text { treatment }\end{array}$ & $\begin{array}{c}\mathrm{Rm}, \\
\mathrm{N} / \mathrm{mm}^{2}\end{array}$ & $\begin{array}{c}\text { Rs, } \\
\mathrm{N} / \mathrm{mm}^{2}\end{array}$ & $\begin{array}{c}\mathrm{E}, \\
\%\end{array}$ & $\begin{array}{c}\mathrm{Kv}, \mathrm{J}, \\
\text { at }-20^{\circ} \mathrm{C}\end{array}$ \\
\hline $\mathrm{CO}_{2}$ & As welded & $510-600$ & $\geq 420$ & $\geq 24$ & $\geq 50$ \\
\hline
\end{tabular}

Tab. 4. Mechanical properties of the deposited metal

\section{CONCLUSIONS}

The advantages of using flux cored arc welding (FCAW) are: quality of the weld, increase productivity, reduced distortion etc. Problems regarding noxes, their effect, measurements as well as a review of respiratory protective devices are presented also. The case study completes the data presented in the paper.

\section{REFERENCES}

Jenkins, N.T. (2005). Particle size distribution of gas metal and flux cored arc welding fumes, Welding Journal, Vol. 84, No. 10, oct., pp. 156s-163s, ISSN: 0043-2296

Liberty, G. (2004). Studio della formazione di fumi emessi da un processo FCAW sotto protezione di $\mathrm{CO}_{2}$, Rivista Italiana della Saldatura, No. 3, pp. 386-388, ISSN: 00356794

Popescu, M., Mocuţa, E.G., Vartolomei, M. (2009). Welding: Integrated quality, environment and safety management system, Annals of DAAAM for 2009 \& Proceedings of the 20th International DAAAM Symposium, Volume 20, No. 1, ISSN 1726-9679, ISBN 978-3-901509-70-4, Editor B. Katalinic, Published by DAAAM International, Vienna, Austria, EU, 25 - 28 nov. 2009, pp. 0977 - 0978, ISSN: 1726-9679

Popescu, M., Marta, C., Mocuţa, G. E., Opriş, C. (2010). Mechanical Ventilation in Welding, Proceedings of the Annual Session of Scientific Papers "IMT Oradea" 2010, pp. 383-386, ISBN 978-606-10-10-0128-6

*** (2011) www.boehler-welding.com, Accessed on: 2011-0314 